\title{
CFRP/CFRTP とマルチマテリアルの接合
}

2. $\mathrm{CFRTP}$ と $\mathrm{Al} の$ 異種接合

\section{Joining of CFRP/CFRTP and Multi-Material \\ II : Dissimilar Bonding of CFRTP and Al}

by

\section{Atsushi HOSOI*}

Key words: CFRTP, Aluminum, Nanostructure, Bonding strength

\section{1 緒言}

我が国の温室効果ガス排出量の 9 割を占めるエネルギ 一起源二酸化炭素の排出量は, 2013 年度に 12 億 3500 万 トンであり，日本は，2030 年度に 2013 年度比 $26 \%$ 削減 の 9 億 2700 万トンに減らすことを明言している ${ }^{11}$. エネ ルギー起源二酸化炭素の排出量の中で輸送部門は約 18\%を占める。このような背景を踏まえ，次世代の航空 機機体や自動車車体などの輸送機器を軽量化すること によって省然費化を図り, $\mathrm{CO}_{2}$ 排出を削減することは喫 緊の課題となっている.

炭素繊維強化プラスチック（CFRP） は軽量かつ高強 度であることから輸送機器構造の軽量化に適した材料 である.その一方, CFRP の材料コストが高いことから， マルチマテリアル構造にせざるを得ない，その場合に金 属部材と接合部を設ける必要が生じる．例えば，航空機 機体の CFRP と金属の接合にはリベットやボルトなどの 機械的締結が採用されている。しかし，リベットやボル トの総重量が大きくCFRP の軽量特性が活かしきれてい ない。そのため接着剤による接合も検討されているが, 品質保証の課題が残されている. 今後, 持続可能な社会 を構築する上で,リサイクル性に優れた熱可塑性樹脂を 母材とした炭素繊維強化プラスチック（CFRTP）と金属 の接合技術の開発が求められている。しかし，一般に熱 可塑性樹脂は化学的に不活性で接着特性に優れない。熱 可塑性樹脂と金属の接合には，金属に表面処理が施され る。その一つに，化学処理により金属表面にポーラス構 造を作り，アンカー効果によって接合することで高い接 合強度が得られる。ただし, ポーラス構造内部に樹脂を 含浸させる必要があり, 射出成形などの手法がとられて いる。その他にもレーザー加熱技術を利用した CFRTP と亜鉛メッキ鋼材の接合技術 ${ }^{2)}$, 高速回転ツールを利用 した CFRTP とアルミニウム合金の摩擦重䄈接合技術 ${ }^{3)}$, 超音波振動ツールを利用した CFRTP とアルミニウム合 金の熱溶着技術 4)-6)，高速回転ピンの摩擦熱を利用した CFRTP とアルミニウム合金のスポット接合技術 7)-99，渦 電流による誘導加熱による CFRTP とアルミニウム合金 の接合技術 ${ }^{10)}$ などが提案されている.

近年ではアルミニウム合金表面にナノ突起構造を作 製しアンカー効果による機械的締結とシランカップリ ング処理による化学的接合の両方を組み合わせ，ホット
プレスによる熱溶着によって高強度に CFRTP 積層板と 接合可能な技術が開発されている ${ }^{11)}$. 本講座では，その 接合技術について紹介する。

\section{2 表面ナノ構造の作製}

アルミニウム合金に陽極酸化処理を施すことで，表面 の酸化被膜の自己組織化によってナノポーラス構造を 形成できる. そのナノポーラス構造を適度にエッチング することでナノ突起構造を作製可能である ${ }^{12)}$. 図 1 にそ の概略図を示す。具体的には，アセトン中でアルミニウ ム試験片を超音波洗浄した後に，クエン酸とエチレング リコールの混合溶液を電解液とし, 印加電圧 $400 \mathrm{~V}$ の条 件で陽極酸化処理を行う. 陽極酸化処理条件を表 1 に示 す.この陽極酸化処理によって図 2 に示すような酸化ア ルミニウムのナノポーラス構造がアルミニウム表面に 自己組織化される。ポーラス部の厚さ，平均孔径，およ び孔密度は, 約 $2 \mu \mathrm{m}, 200 \mathrm{~nm}, 2.09 \times 10^{8}$ pore $/ \mathrm{cm}^{2}$ であ った.このポーラス構造に対して, 表 2 に示寸条件でリ ン酸およびクロム酸の混合溶液に浸しエッチングする ことで, 図 3 に示すような突起構造の表面ナノ構造を得 ることができる. 図 2 および図 3 はアルミニウム A 1050 の事例であるが，処理条件を選定することで，その他の アルミニウム合金や, チタン, ステンレス鋼などにも応 用できる ${ }^{11), 13), 14)}$.

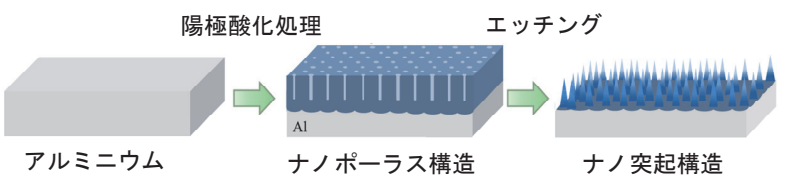

図 1 ナノ突起構造作製プロセスの概略図

表 1 陽極酸化処理条件

\begin{tabular}{|c|c|}
\hline 電解液 & $\begin{array}{c}2 \mathrm{wt} \% \text { クエン酸 }+ \\
2 \mathrm{wt} \% \text { エチレングリコール }(2: 1)\end{array}$ \\
\hline 電圧 V & 400 \\
\hline 電流密度 $\mathrm{mA} / \mathrm{cm}^{2}$ & 16.7 \\
\hline 時間 hours & 9 \\
\hline 処理温度 ${ }^{\circ} \mathrm{C}$ & 10 \\
\hline
\end{tabular}

+ 原稿受理＼cjkstart令和元年12月6日Ｒeceived Dec.6, 2019@2020 The Society of Materials Science, Japan

* 正 会 員 早稲田大学理工学術院基幹理工学部機械科学・航空宇宙学科 ₹ 169-8555 東京都新宿区大久保, Dept. of Appl. Mech. Aero. Eng., Waseda Univ., Shinjuku-ku, Tokyo, 169-8555 


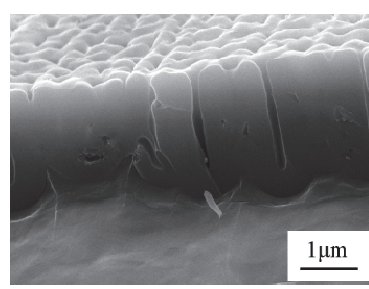

(a)

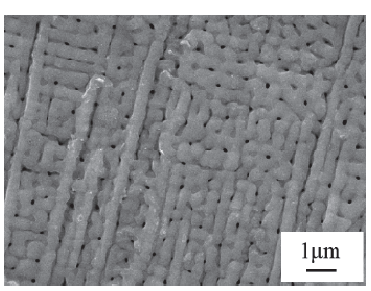

(b)
図 2 陽極酸化処理を施したアルミニウム表面のナノポ 一ラス構造の観察画像 : (a)側面形状 ; (b)表面形状

\begin{tabular}{cc} 
表 2 & エッチング条件 \\
\hline エッチング液 & $6 \mathrm{wt} \%$ リン酸 + \\
エッ & $1.5 \mathrm{wt} \%$ クロム酸 $(1: 1)$ \\
処理温度 ${ }^{\circ} \mathrm{C}$ & 63 \\
時間 minutes & 48 \\
\hline
\end{tabular}

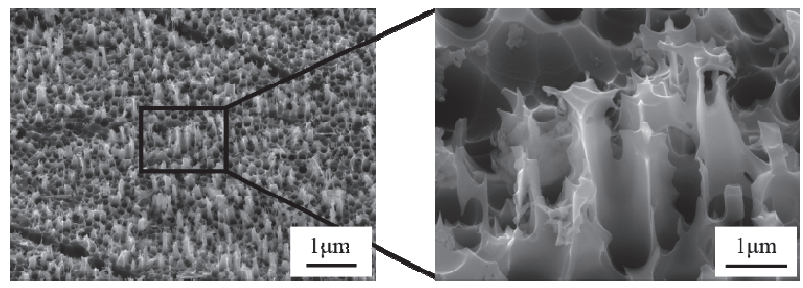

図 3 陽極酸化処理およびエッチング処理を施したアル ミニウム表面のナノ構造

\section{3 接合方法}

ナノ構造を有するアルミニウム合金表面に CFRTP 母 材樹脂に適したシランカップリング処理を施すことで， さらに結合強度を向上させることができる．本報では表 3 に示すような母材樹脂にPA6を用いた熱可塑性 CFRTP （CF/PA6）積層板を用いて評価を行った。一例としてナ イロン系の樹脂の場合にはイソシアネート基を有する シランカップリング材が有効である. CF/PA6 積層板と 表面処理を施したアルミニウム A1050 をホットプレス によって熱溶着させる。アルミニウム側のホットプレー 卜を 290 度に加熱し, 約 $0.1 \sim 0.4 \mathrm{MPa}$ 程度に加圧し接合 させた。

\section{表 3 CFRTP 積層板の諸元}

\begin{tabular}{|c|c|}
\hline 母材 & Polyamide 6 (PA6) \\
\hline 融点 $\left[{ }^{\circ} \mathrm{C}\right]$ & 225 \\
\hline 繊維体積含有率 $V_{\mathrm{f}}[\%]$ & 50 \\
\hline 炭素繊維 & Toray T300B-3K (平織) \\
\hline 積層構成 & {$\left[(0 / 90)_{9}\right]_{\mathrm{T}}$} \\
\hline
\end{tabular}

\section{3 接合強度特性}

接合強度を評価するために図 4 に示寸形状のシングル ラップジョイント試験片を用いた．異種材料の接合強度 を評価するにあたって, 各材料の剛性が異なることから シングルラップジョイント試験では曲げの影響を受け,
通常, 純粋なせん断強度を得られないことに注意を要す る. 近年，樹脂と金属の異種接合材の接合界面特性評価 法として ISO 規格 (19095 シリーズ) が制定されている.

今回は JIS K 6850，ASTM D1002 を参考にシングルラッ プジョイント試験片を作製し，静的引張せん断試験を行 った. 試験片の形状は CFRTP 積層板,アルミニウムと もに, $100 \mathrm{~mm} \times 25 \mathrm{~mm} \times 2.0 \mathrm{~mm}$ であり，接合部のオー バーラップ長さを $12.5 \mathrm{~mm}$ または $5 \mathrm{~mm}$ とした. 試験機 の引張速度は $1.0 \mathrm{~mm} / \mathrm{min}$ である。

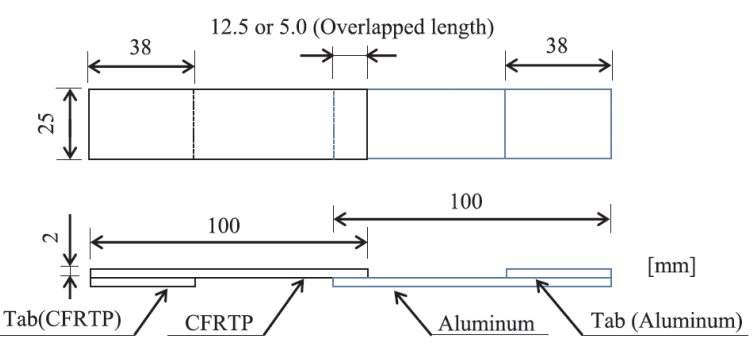

図 4 シングルラップジョイント試験片

接合部のオーバーラップ長さを $12.5 \mathrm{~mm}$ として接合さ せると，図 5 に示すようにアルミニウム部で破断するほ ど高い接合強度を有する結果が得られた。そこで, 表面 ナノ構造やシランカップリング剤の影響を評価する場 合には，試験片接合部で破断させるために，オーバーラ ップ長さを $5.0 \mathrm{~mm}$ として評価を行った. その接合強度 結果を図 6 に示寸.

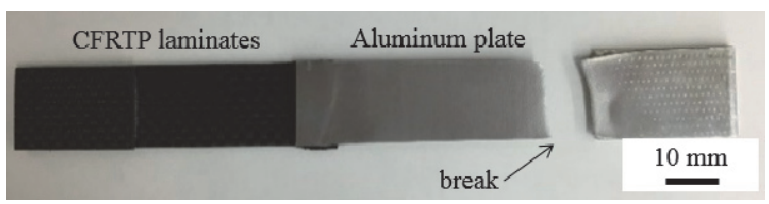

図 5 静的せん断試験後の観察写真

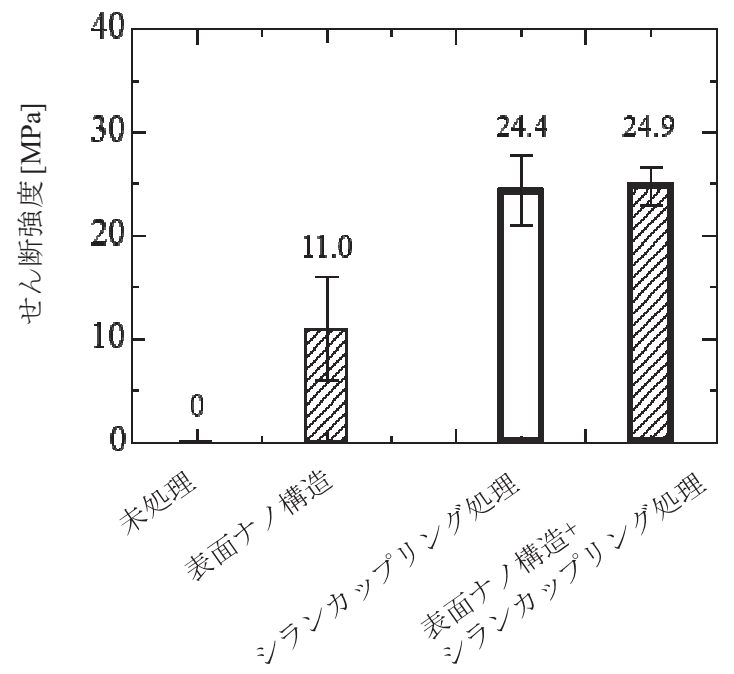

図 6 各表面処理におけるせん断強度特性 
図 6 に示した結果から未処理の試験片ではせん断強度 が 0 であり, 表面処理を施さないアルミニウムと CF/PA6 は接合しないことが分かる。一方，図 3 に示したような 表面ナノ構造をアルミニウム表面に付与することで約 $11.0 \mathrm{MPa}$ のせん断強度を発現することが分かる。これは 表面のナノ構造のアンカー効果によるものである. ホッ トプレスによる接合において, 表面構造がポーラス構造 の場合は，孔内に存在する空気によって樹脂の含浸が妨 げられることから，高い接合強度は期待できない。エッ チングを施すことで, 突起構造にするなど空気の逃げ道 を作ることで，ホットプレスによる熱溶着においても高 い接合強度を発現させることができる．また，シランカ ップリング処理による化学結合だけでも $24.4 \mathrm{MPa}$ と高 いせん断強度を発現させることができる。シランカップ リング剂のイソシアネート基とポリアミド 6 がウレア結 合したためであると考えられる. 表面ナノ構造とシラン カップリング処理を施した結果では，せん断強度は24.9 $\mathrm{MPa}$ とシランカップリング処理のみの結果とほとんど 変わらない。これはナノ構造の影響がないのでは無く, 破壊が接合界面ではなく CF/PA6 の母材樹脂で生じたた めである。つまり，接合強度特性が母材樹脂の破壊特性 に支配された結果，ナノ構造の影響が現れなかったと考 えられる. 母材に PA6より強度特性の高い樹脂を用いる ことで，更なる接合強度向上が見込まれる。

\section{4 破面観察による評価}

表面ナノ構造とシランカップリング処理を施し，接合 させた試験片の破面形態の概略図を図 7 に示す。アルミ ニウム表面に樹脂が全面的に付着し, 平織 CF/PA6 積層 板の織り目が交差するレジンリッチ部分はアルミニウ 么部分に付着して残る.図 8 に示した走査型電子顕微鏡 (SEM) による観察では，特に CFRTP 側の平織構造の 織り目交差部で炭素繊維が露出することが観察される.

シランカップリング処理のみを施した試験片の破面 と表面ナノ構造とシランカップリング処理を施した試 験片の破面では特徵的な違いが観察された. 図 9 はシラ ンカップリング処理のみを施した場合の CFRTP 側の破 面とアルミニウム側の破面の SEM 画像をそれぞれ示し ている.アルミニウム側の破面では薄く母材樹脂が張り 付いていることが分かる.また，CFRTP 側の破面も平滑 でありぜい性的に破壊が進行したことが見て取れる。一 方, 図 10 は表面ナノ構造とシランカップリング処理を 施した CFRTP 側の破面を観察した SEM 画像を示してい る。ナノ構造の影響によって樹脂が毛羽立ったような延 性破壊を伴いながら破壊が進行する様子が見て取れる. 図 10(b)では織り目の交差するレジンリッチ部であるが, 纎維が界面破壊している様子も観察された。

以上の結果から図 6 に示したせん断強度試験の結果で は，シランカップリング処理を施した試験片について， 表面ナノ構造の有無によって接合強度に大きな差はな いが，破壊形態に違いが観察された．表面にナノ構造が 無い場合, き裂前縁では 3 軸引張り応力状態となりぜい 性破壊が誘起されたものと考えられる。一方, 表面にナ ノ構造を有することで, き裂前縁の応力場が変化し最大 せん断応力が増大した結果, 樹脂の延性破壊が誘起され たものと思われる。この延性破壊が生じる効果によって 破壊じん性が大幅に向上することも最近の研究で明ら

かにされている.つまり，金属表面のナノ構造によるア ンカー効果とシランカップリング処理による化学結合 の両方を組み合わせることによって, 接合強度と層間破 壊じん性の両方を向上させることができる.

CFRTP

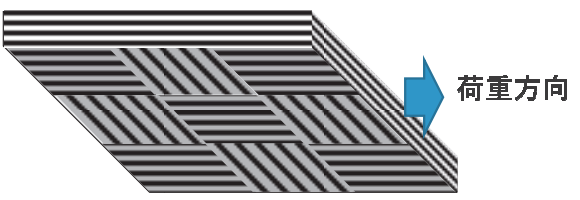

荷重方向

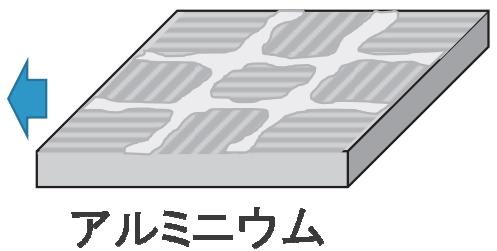

困 7 破面形態の模式図

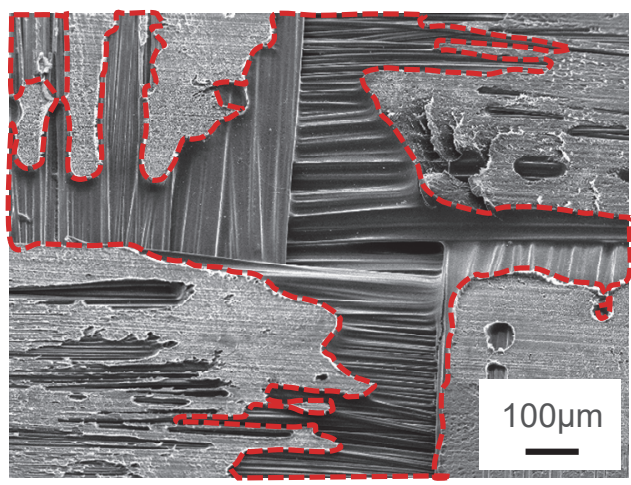

図 8 CFRTP 織り目交差箇所の SEM 観察画像

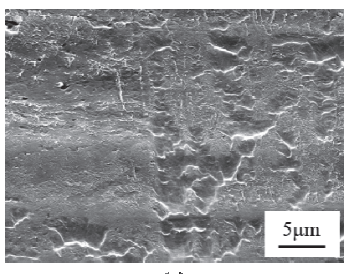

(a)

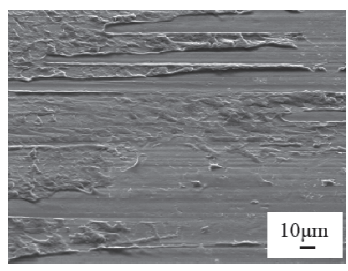

(b)
図 9 シランカップリング処理を施した試験片破面の SEM 観察画像：(a) CFRTP 表面 ; (b)アルミニウム表面

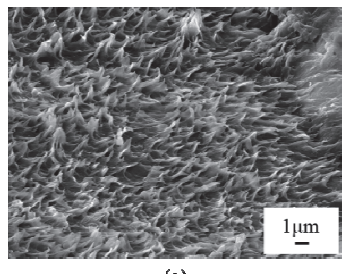

(a)

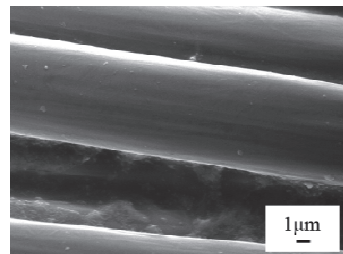

(b)
図 10 表面ナノ構造とシランカップリング処理を施し た CFRTP 側破面の SEM 観察画像 : (a) CFRTP 表面の繊 維束領域; (b) CFRTP 表面の織り目領域 


\section{5 非破壊検査}

CFRP や CFRTP と金属などの接着において, 品質保証 が 1 つの大き課題となっている. 接着は接合条件によ ってはウィークボンドが生じることがある．航空機の一 次構造部材に接着継手が採用されない理由の 1 つは，ウ イークボンドを定量的に検出できる技術が確立されて いないからである。ここでは，トライアルとして，シラ ンカップリング処理を施したアルミニウム合金 A5052 と CF/PA6 をホットプレスにより熱溶着した試験片に対 し, 接合部の超音波応答と引張せん断試験により得られ た接合強度との関係性を評価した結果について紹介す る $^{15)}$.

ウィークボンドを意図的に作製するために接合温度 を 240-300Cの条件でホットプレスにより接合し, 眓 4 に示すシングルラップジョイント試験片を作製した。非 破壊検查には空中超音波探傷装置を用い $400 \mathrm{kHz}$ 焦点型 のセンサにより接合部を走査した. その後，静的せん断 試験を実施し, 超音波応答と接合強度の関係を評価した。

表 4 は各接合温度と超音波応答, アルミニウム合金破 断面と接合強度を示している。超音波応答については, 色が赤いほど超音波の透過強度が高く，青いほど透過強 度が低いことを示している。アルミニウム合金の破面は 白っぽくなっている部分は樹脂が付着した箇所である.

表 4 接合温度と超音波応答，アルミニウム合金破断面 と接合強度

\begin{tabular}{|c|c|c|c|}
\hline $\begin{array}{l}\text { 接合 } \\
\text { 温度 }{ }^{\circ} \mathrm{C}\end{array}$ & 超音波応答 & A5052 破断面 & $\begin{array}{c}\text { 接着強度 } \\
\mathrm{MPa}\end{array}$ \\
\hline 300 & 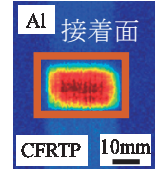 & 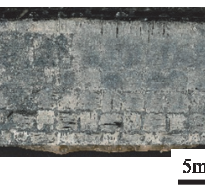 & 24.1 \\
\hline 290 & CFRTP & & 7.04 \\
\hline 280 & $\begin{array}{l}\text { Al } \\
\text { CFRTP } \\
\end{array}$ & & 12.2 \\
\hline 260 & \begin{tabular}{|l}
$\mathrm{Al}$ \\
CFRTP \\
\end{tabular} & & 5.80 \\
\hline 250 & CFRTP & & 0.16 \\
\hline
\end{tabular}

接合温度 $300^{\circ} \mathrm{C}$ 結果では，超音波の透過強度が高く なっており，接合強度も高い。その結果アルミニウム合 金破面全体に樹脂が付着している様子が見て取れる。接 合温度 $290^{\circ} \mathrm{C}$ の結果では, 試験片接合部右側の超音波透 過強度が高く，破面の樹脂付着も同様の傾向を示してい る. 接合温度 $280^{\circ} \mathrm{C}$ の結果では, 接合温度 $300^{\circ} \mathrm{C}$ の結果 と比較すると超音波透過強度は全体的に低く, 樹脂の付 着量も全体的に少ない. その結果接着強度も低下してい ることが見て取れる。接合温度 $250^{\circ} \mathrm{C}$ の結果では, 超音 波はほとんど透過しておらず破面に樹脂の付着はほと んど見られない。また，接合強度もほぼ 0 であった。こ れらの超音波透過強度と接合強度の関係を図 11 に示寸. 図から多少のバラつきはみられるが, 接合強度と超音波 透過強度に相関関係があることが見て取れる. なお，図 6 に示したせん断強度と結果が異なる理由は，用いたア ルミニウム合金が異なることと, オーバーラップ長さが 異なることによる. 本研究ではシランカップリング材を 用いた化学結合により接合していることから, 接合界面 の化学反応によって樹脂の密度や結晶化度が変化して このような相関が得られたものと思われるが, その原理 については明らかとなっておらず, 今後の研究課題であ る.

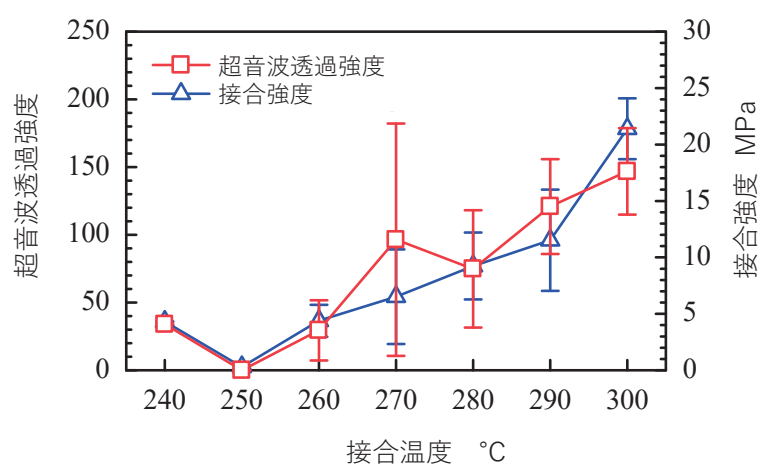

図 11 各接合温度における超音波透過強度と接合強度 の関係

\section{6 プレス成形への応用}

図 12 はホットプレスで成形した厚さ $0.5 \mathrm{~mm}$ の CFRTP とアルミニウムの接合薄板の写真を示している. 非対称 積層板であるため, 熱残留応力が生じることにより反り が生じている，図 13 はこの薄板からプレス成形するこ とでスマートフォン筐体を賦形したものである.アルミ ニウム単体と比較して約 $25 \%$ の軽量化が可能である。
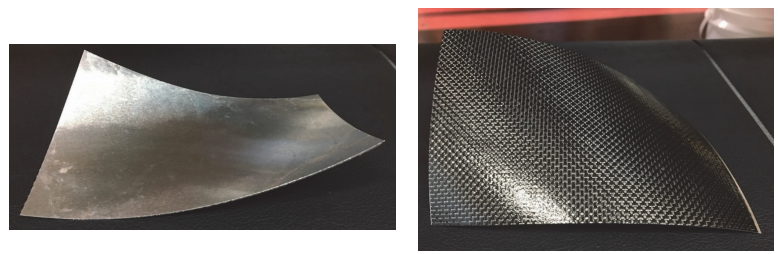

図 12 ホットプレスで成形した厚さ $0.5 \mathrm{~mm}$ の CFRTP とアルミニウム成形板 


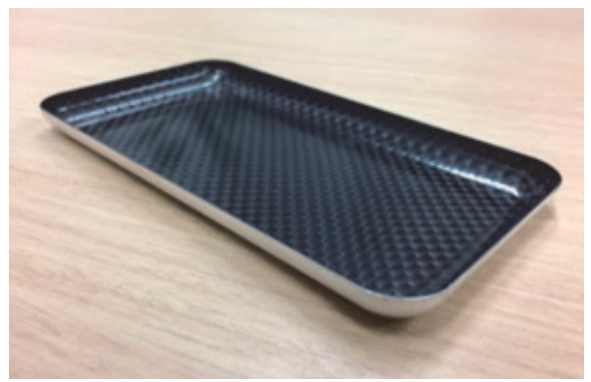

図 13 プレス成形によるスマートフォン筐体

\section{7 今後の展望}

本報では CFRTP とアルミニウムにおける異種接合技 術について紹介した．金属表面のナノ構造によるアンカ 一効果とシランカップリング処理による化学結合の両 方を組み合わせることで，接合強度と破壊じん性の両特 性を向上させることが可能である。この接合技術ではホ ットプレスによって接合できることから寸法や板厚な どの形状の制限が少ない利点がある。今後, 輸送機器や 電子機器分野など様々な分野において CFRTP と金属の 異種接合技術の応用展開が期待される.

\section{参考文献}

1) Ministry of the Environment website: https://www.env.go.jp/earth/ondanka/ghg/2020.html

2) K.W. Jung, Y. Kawahito, M. Takahashi and S. Katayama, "Laser direct joining of carbon fiber reinforced plastic to zinc-coated steel", Materials \& Design, Vol. 47, pp. 179-188 (2013).

3) K. Nagatsuka, S. Yoshida, A. Tsuchiya and K Nakata "Direct joining of carbon-fiber-reinforced plastic to an aluminum alloy using friction lap joining", Composites Part B-Engineering, Vol. 73, pp. 82-88 (2015).

4) F. Balle, G. Wagner and D. Eifler, "Joining of aluminium 5754 alloy to carbon fiber reinforced polymers (CFRP) by ultrasonic welding", Aluminum Alloys: Fabrication, Characterization and Applications II, pp. 191-196 (2009).

5) F. Balle and D. Eifler, "Statistical test planning for ultrasonic welding of dissimilar materials using the example of aluminum-carbon fiber reinforced polymers (CFRP) joints", Materialwissenschaft und Werkstofftechnik, Vol. 43, No. 4, pp. 286-292 (2012).

6) G. Wagner, F. Balle and D. Eifler, "Ultrasonic welding of aluminum alloys to fiber reinforced polymers", Advanced Engineering Materials, Vol. 15, No. 9, pp. 792-803 (2013).

7) S.M. Goushegir, J.F. dos Santos and S.T. Amancio, "Influence of process parameters on mechanical performance and bonding area of AA2024/carbon-fiber-reinforced poly (phenylene sulfide) friction spot single lap joints", Materials \& Design, Vol. 83, pp. 431-442 (2015).
8) S. M. Goushegir, "Friction spot joining (FSpJ) of aluminum-CFRP hybrid structures", Welding in the World, Vol. 60, No. 6, pp. 1073-1093 (2016).

9) N. M. Andre and S.M. Goushegir, J.F. dos Santos, L.B. Canto and S.T. Amancio, "Friction Spot Joining of aluminum alloy 2024-T3 and carbon-fiber-reinforced poly (phenylene sulfide) laminate with additional PPS film interlayer: Microstructure, mechanical strength and failure mechanisms", Composites Part B-Engineering, Vol. 94, pp. 197-208 (2016).

10) P. Mitschang, R. Velthuis, S. Emrich, and M. Kopnarski, "Induction heated joining of aluminum and carbon fiber reinforced nylon 66". Journal of Thermoplastic Composite Materials, Vol. 22, No. 6, 767-801 (2009).

11) H. Abe, J.C. Chung, T. Mori, A. Hosoi, K.M. Jespersen and H. Kawada, "The effect of nanospike structures on direct bonding strength properties between aluminum and carbon fiber reinforced thermoplastics", Composites Part B: Engineering, Vol. 172, pp. 26-32 (2019).

12) R. Yu, K.L. Ching, Q.F. Lin, S.F. Leung, D. Arcrossito and Z.Y. Fan, "Strong light absorption of self-organized 3-D nanospike arrays for photovoltaic applications" ACS NANO, Vol. 5, No. 11, pp. 9291-9298 (2011).

13) J. Macák, H. Tsuchiya and P. Schmuki, "High-aspect-ratio $\mathrm{TiO}_{2}$ nanotubes by anodization of titanium”, Angewandte Chemie International Edition, Vol. 44, pp. 2100-2102 (2005).

14) W. Zhan, H. Ni, R. Chen, X. Song, K. Huo and J. Fu, "Formation of nanopore arrays on stainless steel surface by anodization for visible-light photocatalytic degradation of organic pollutants", Journal of Materials Rsearch, Vol. 27, pp. 2417-2424 (2012).

15) K. Okamoto, J.C. Chung, H. Abe, A. Hosoi, N. Ishida, S. Matsukawa, K.M. Jespersen and H. Kawada, "Direct bonding between carbon fiber reinforced thermoplastics and aluminum alloys and its soundness evaluation by non-contact ultrasonic testing", Proceedings of 26th International Conference on Composites/Nano Engineering, (2018) (on Web-site). 